\title{
Women in Hospitality Management: General Managers' Perceptions of Factors Related to Career \\ Development
}

\author{
Judi Brownell \\ Cornell University
}

Judi Brownell, School of Hotel Administration, Cornell University, Ithaca, NY 14853. 


\begin{abstract}
A descriptive study was undertaken to learn more about women's career development in the hospitality industry from general managers' perspectives. The primary purpose of the study was to identify the communication skills and job-related activities that were perceived to have contributed most significantly to individuals' advancement, and to determine any differences between men's and women's perceptions regarding the most essential competencies and behaviors for advancement in the hospitality industry. Both groups rated the significance of eight potential obstacles to women's career development. Demographic information was gathered to determine whether significant differences existed between the samples of men and women.
\end{abstract}

The samples of both men and women ranked listening competence as the most important communication skill for career advancement in the hospitality industry, followed by group leadership skills. Perceptions regarding the behaviors and/or circumstances that contributed to career development were also similar between the two groups; both ranked (1) hard work, (2) a positive attitude and (3) communication effectiveness as the three most essential items. The only significant difference between the two groups was with regard to the role mentoring played in mens' and womens' career development.

The relative ranking of various obstacles to women's career development was similar between the samples of men and women; however, significant differences existed in the degree to which each group felt these items posed a problem to women in hospitality management.

Keywords: women, career development, hospitality management, general managers perceptions 


\section{Women in Hospitality Management: General Managers' Perceptions of Factors Related to Career Development}

\section{Introduction}

As more women move into hospitality management, it becomes ever more critical to understand the variables that affect their career development and to identify the kinds of initiatives that can be taken to facilitate women's career progress. This study examines general managers' perceptions of the specific communication competencies women need to be successful in the lodging industry, and identifies the factors or circumstances that appear most likely to have an impact on career advancement. Since it has also been suggested that women confront gender-related obstacles in the workplace, perceptions of the special challenges women encounter are also examined.

Researchers, educators, and practitioners alike have been troubled by the fact that women have not made more substantial career progress during the past several decades; a growing body of literature now documents this concern (Wentling, 1992; DelSesto, 1993; Williams and Hunter, 1992; Silberman, 1991; Fernsten et al., 1988). Fortune magazine, for example, recently polled 201 chief executives of the nation's largest companies. Only 16\% of these respondents believe it is either very or somewhat likely that within the next 20 years, a woman will be heading their company. On the same note, Segal and Zellner (1992) explain that, at the current rate of progress over the past two decades, it would take another 475 years for women to be equally represented in leadership positions. In its 83-year history, the American Hotel \& Motel Association has had only one woman chairperson. In spite of the increasing similarities in the background and experience of men and women in management, women remain poorly represented at the senior level. 
The U.S. Department of Labor defines the glass ceiling as a composite of 'artificial barriers based on attitudinal or organizational bias that prevents qualified women from advancing upward in their organizations into senior management level positions' (1991, p. 1). Recent studies have found that perceived lack of opportunity for career advancement is one of the major reasons why women, many of them possessing 'all the right stuff' (Stroh et al., 1992;

Kalinowski, 1989; Ostroff, 1993), leave their organizations (Rosin and Korabik, 1990; Trost, 1990; Snyder, 1993). The hospitality industry is no exception. Although just as many women are being graduated from programs in hospitality management as men, they are leaving the industry at up to three times the rate of their male counterparts (Gregg and Johnson. 1990; Brownell, 1991b).

A number of explanations have been proposed. Two of the most common barriers identified in the research literature are the old boy networks, and the lack of mentors (DeLuca, 1988; Rosen et al., 1982; Brass, 1985; Haskell, 1991; Ragins and Cotton, 1991; Carbone, 1992; Ibarra, 1993; Campbell, 1988; Wentling, 1992; Noe. 1988). Excluded from many of the informal information networks, or what Rossi (1966) has called 'interpersonal environments', careerrelevant information is more difficult for women to obtain. Women are also less likely to receive the feedback and recognition that is essential to their advancement (McCarty, 1986; DeWine and Smith, 1991). In addition, a number of researchers (Scandura, 1992; Burke and McKeen, 1990; Dreher and Ash, 1990) propose that women often do not receive the sponsorship necessary to move into upper level management. Noe (1988), for instance, believes that the mentoring relationship provides a protegee with access to the dominant coalitions, and that women without mentors 'may not be visible to organizational decision makers' (p. 67). 
Issues regarding conflicts between family and work also affect women's career development, especially in hospitality environments. As Lobe1 (1991) explains, it is employers' preconceived notions of the impact family obligations will have on a woman's career that is the major problem. In cases where employers believe that family responsibilities will interfere, it is likely that they will not only be reluctant to hire the individual, but will also expect her performance to be affected by family concerns. A self-fulfilling prophecy is likely to result. Although in such cases the problems of women's advancement may have more to do with stereotypes than with the behavior of the women themselves (Fisher, 1992), it may be useful to further explore the specific behaviors and activities associated with women who have attained senior level positions in hospitality management.

\section{Study}

Much of our information about women's career development has come from surveys of middle managers or from in-depth interviews with a small sample of women executives. Another approach to learning more about women's career development is to survey a broader sample of men and women who have been successful in the hospitality industry. This descriptive study examines general managers' perceptions regarding the communication skills and job-related activities that they believe contributed most significantly to their career development, and identifies differences between men's and women's perceptions of the most essential competencies and behaviors for advancement in the lodging industry.

In addition, both groups rated the significance of eight potential obstacles to women's career development. This portion of the study builds directly on earlier work (Brownell, 1993) focusing on the perceptions of women in middle hospitality management who were asked to rate 
identical items. Demographic information was also gathered to determine whether significant differences existed between the samples of men and women.

The lodging industry provides a particularly rich environment in which to study career development, since advancement often occurs over a period of time and individuals may progress down a variety of paths as they move through the organizational structure. The numbers of women in general management positions in the lodging industry also provides a reliable study sample. Ultimately, any knowledge gained will enable both educators and practitioners to better

analyse the hospitality workplace and better prepare women for moving into senior level management positions.

\section{Methodology}

\section{Subjects}

The sample of women general managers was derived from the twenty largest, domestic lodging companies as listed by number of rooms in the 1992 AH\&MA directory. Only the general managers of 'full service' hotels were surveyed; full service properties were defined as those that provided food and beverage outlets and such other services as room service, bell and valet service, a concierge, laundry service, recreational and meeting facilities, a business center, and other similar amenities. Full service properties were distinguished from those with limited services because it was assumed that these organizations were more likely to provide an environment where managers would confront a range of workplace challenges due to role relationships, status, and the like. United States companies were selected to rule out variations in career development due to cultural differences. 
The Vice President of Human Resources Management of each of the twenty hospitality companies was contacted, first in writing and then by telephone. The purpose of the study was explained, and the corporate representative was invited to participate by providing the names and addresses of all current women general managers. Nineteen companies participated; women from sixteen of these were represented in the final sample. The total number of women general managers identified by the human resource management vice presidents or a designated corporate representative was 124 . After the initial mailing and two follow-up mailings of the questionnaire, the number of respondents for the sample of woman was 97 , or $78.2 \%$.

The properties managed by women were then deleted from each of the participating company's directory, and a stratified random sample of general managers from the remaining properties was surveyed. A total of 317 questionnaires were sent. It was presumed that these respondents would be male and, indeed, in every case the returned survey indicated the respondent's gender as male. The initial response rate was $60.5 \%$; after two follow-up mailings, the final response was 221 or $69.7 \%$.

\section{Survey Design and Procedure}

The survey instrument was developed after in-depth interviews with six female and four male general managers regarding their careers and the issues they believed were important to address regarding career development. An extensive literature review was undertaken to determine the variables associated with mobility in organizations generally and advancement in the hospitality industry in particular (Anthony, 1986; Christensen, 1987; Cohen and Neilson, 1988; Fernsten et al., 1988; Williams and Hunter, 1992; DelSesto, 1993; Lobe1 and St. Clair, 1992). The literature on women in management and issues related to the glass ceiling was also examined (Bernstein, 1990; Blanksby, 1987; Carbone, 1992; Wentling, 1992: Snyder, 1993). 
Among the categories most frequently mentioned in the initial interviews and in the career development literature as influencing managers' career development were: demographic variables (such as time in the industry and educational preparation), personality characteristics, communication and leadership skills, and a set of related factors or circumstances including such things as hard work, lucky breaks, and personal sacrifice. There were also a number of items that were perceived as potential obstacles to women's career development. It was determined that leadership as a concern was beyond the scope of this study, but that information could be obtained on demographic variables, communication skills, and relevant career-related activities that would provide a clearer picture of women's career development and the ways in which it might differ from traditional male patterns.

Content analysis of the ten transcribed interviews and the data collected from literature reviews was performed by two trained coders and the primary researcher. Employing this method, specific items were identified for use in sections of the survey covering (1) key managerial communication skills and (2) career-related activities/circumstances perceived to affect career development. In each case, items were included if they were mentioned by at least seven of the ten general managers interviewed and also recurred in the literature as they contributed to career advancement or as they explained differences in career development between men and women.

Potential obstacles to women's career development were also generated and compared to a previous list developed by Brownell (1993) in her study of women in middle hospitality management. The original items required only minor modifications to incorporate aspects mentioned by general managers. 
The first section of the survey requested demographic information. Respondents were asked to indicate such items as their age, marital status, educational background, years of experience in the hospitality industry, and other pertinent information. The second section of the survey focused on respondents' perceptions of key career development communication practices and career-related activities. Finally, respondents were asked to indicate the extent to which they perceived various items as obstacles to women's career advancement in the lodging industry.

\section{Analysis}

Descriptive statistics and content analysis were used to analyse survey results.

Frequencies and percentages were derived for the sample of men and women separately as well as for the entire group of participants. Means and standard deviations were also determined, when appropriate, for the sample of women managers, the sample of male managers, and the combined group. In several instances $t$ tests were performed to determine whether significant differences existed between female and male samples.

\section{Results}

\section{Demographic differences Between Men and Women General Managers}

The women respondents, as a whole, were younger than their male counterparts (Table 1). While over $15 \%$ of the women general managers surveyed were under 30 , the same was true of only $5 \%$ of the men. The percentage of the sample of women who were under $35(40.2 \%)$ was almost twice that of the male population $(21.1 \%)$. The sample of general managers as a whole fell largely into the middle age range, with over $55 \%$ of the respondence placing their age between 36 and 45 years. Consequently, there was also a notable difference in the number of years men and women have spent in the industry (Table 1). Four times more women than men 
have worked in lodging organizations fewer than 10 years, while over six times as many men as women have worked in the industry over twenty years.

Marital status has been linked to the ease with which individuals are able to pursue their careers (Chusmir, 1982; Lambert, 1990; Schwartz, 1989), and striking differences appeared in this study with regard to the numbers of men and women who were married. Nearly $35 \%$ of the women indicated they were single, compared to only $6.41 \%$ of the men. Although age may explain some of this difference, there are clearly fewer women than men who have pursued both marriage and general management positions (Table 1). No information was collected to determine the percentage of either men or women who had divorced and remarried.

There were also differences in academic preparation between men and women. Twice as many women as men held degrees from community colleges, while approximately $12 \%$ more men than women held four year degrees. While $7.42 \%$ of men also held graduate degrees, the same was true of only $3.21 \%$ of women. Of particular note is that while less than $10 \%$ of the women holding 4 year degrees earned them in hospitality management (compared to $45 \%$ who did not), over half of the men who held 4 year degrees earned them in hospitality-specific programs. The same was true of their community college degrees as well; nearly half of the men who went to a community college completed programs related to hospitality management.

Of the total sample surveyed, 84\% managed properties that had between 100 and 500 rooms. This proportion was representative of the samples of both men and women. It was at the ends of the continuum, properties of under 100 or over 500 rooms, that gender differences were apparent. While almost $5 \%$ of the women managed smaller properties, no men indicated that they managed properties of less than 100 rooms. On the other hand, while just over $5 \%$ of the 
women managed properties of over 500 rooms, $18 \%$ of the men surveyed indicated that their properties had more than 500 rooms.

\section{Perceptions of the Importance of Communication Skills}

Respondents were asked to rank six communication skills in terms of the importance of each to their career development using a six-point Likert scale that moved from low (1 and 2) to moderate ( 3 and 4 ) to high (5 and 6 ). The communication skills included in the survey were: presentational speaking, group leadership, written communication, oral communication, and providing effective feedback. Table 2 shows the percentage of the total sample that assigned each of the six ratings to the six competencies, and Table 3 provides a comparison of the response means from the samples of men and women.

Overall, men and women were in strong agreement regarding the most and least important communication practices. Both assigned the highest ratings to effective listening (mean 5.52) and group leadership (mean 5.46), and the lowest ratings to presentational speaking (mean 4.24) and clear and persuasive written communication (mean 4.37), with women finding somewhat less value in presentational speaking (mean 4.12) than men (mean 4.30).

On the high side of the 6-point scale, no respondent gave effective listening a rating of less than $4 ; 68.82 \%$ of the women and $55.56 \%$ of the men gave listening the highest possible rating. Although there was strong agreement between the groups of men and women on many variables, a t test revealed a difference of $p<.05$ level of significance between the two samples with regard to perceptions of the importance of effective feedback $(t=-2.28)$. The next greatest difference between the two samples pertained to perceptions of listening, although the $t$ score for listening $(\mathrm{t}=-1.65)$ did not indicate significance at $\mathrm{p}<.05$. 
Oral communication was seen by the sample of general managers to be more important to their career development than written communication. The mean of the total sample regarding the importance of clear and persuasive writing was 4.37 compared to a mean of 5.27 for clear and persuasive oral (interpersonal) communication. Women felt written communication was slightly more helpful to them than did men.

\section{Perceptions of the Importance of Career-Related Activities and Circumstances}

General managers were also asked to indicate the extent to which various activities or circumstances contributed to their career advancement. The items presented to respondents are listed in Table 4: knowledge of the field, personal sacrifice, lucky breaks, hard work, mentoring, personality, attitude, education, problem-solving ability, and communication ability. The range in mean scores for the total sample was 2.20 on a six point scale, from 3.38 for 'lucky breaks' to 5.58 for 'hard work'.

Once again, there were striking similarities between the two samples. Men and women were in agreement on their first, second, third, and forth rankings. Clearly, hard work was viewed as most essential to career advancement in the lodging industry. Hard work was followed by a positive attitude, communication ability, and competence in problem solving. Differences between the means of the two groups on these items were minor.

Although fifth and sixth rankings were reversed for men and women, the means of their ratings were still very similar on these two items, personal sacrifice and personality. Men and women were again in complete agreement regarding the order of the four lowest-ranked items, assigning ratings that resulted in a rank order of: job knowledge (7), mentoring (8), education (9), and lucky breaks (10). Of the ten items, the only differences at $\mathrm{p}<.05$ level of significance 
between the ratings of men and women pertained to mentoring $(\mathrm{t}=2.498)$, with men rating mentoring as more significant to their career development than women.

\section{Importance of Obstacles to Women's Career Development}

Part 3 of the survey requested respondents to indicate the extent to which they believed each of eight items to be an obstacle to women's career development. On 6-point Likert scales, respondents rated each item as 'no/minor' obstacle (1 and 2), 'somewhat' of an obstacle (3 and 4), or a 'major' obstacle (5 and 6). In this question, respondents were asked their perceptions of the current industry situation rather than perceptions of their personal career experiences. Again, data analysis consisted of determining percentages and frequencies, means, standard deviations, and $t$ scores. Table 5 summarizes this information. A review of the data reveals the following findings.

Once again, the samples of men and women were similar in their views of the relative importance of the eight potential obstacles to women's career development. While the sample of women perceived the old boy network (4.42), conflicts between family and work (4.36), and lack of equity in pay and promotions (4.03) as the predominant obstacles, the men ranked conflicts between family and work (4.01), characteristics of the job (3.26), and the old boy network (3.07) as the obstacles they viewed as most troublesome to women in the industry. The two samples were in agreement that sexual harassment and lack of job knowledge were the least significant of the eight items.

What was highly discrepant in all but one case was the extent to which the two samples perceived various obstacles to be problematic. Although there was considerable agreement on the relative importance of each item, there were significant differences between the mean scores assigned by the male and female groups. In fact, the only item for which the two samples did not 
assign scores that resulted in differences at $\mathrm{p}<.05$ level of significance was job knowledge $(\mathrm{t}=-1.42)$. Discrepancies in the degree to which male and female general managers perceived pay and promotions $(\mathrm{t}=-7.61)$, old boy networks $(\mathrm{t}=-7.30)$, and credibility $(\mathrm{t}=-5.75)$ as obstacles were particularly striking.

For example, over $40 \%$ of the male general managers assigned ratings of 1 or 2 ('no/ minor obstacle') to six of the eight items. Over $50 \%$ of the male general managers perceived pay and promotions, sexual harassment, and job knowledge as no/minor problem for women. While $54.24 \%$ of the men viewed pay and promotions as no obstacle or a minor one, only $11.39 \%$ of the women surveyed agreed. Similarly, while $41.22 \%$ of the men perceived old boy networks as a minor obstacle to women's career development, only $8.86 \%$ of the women general managers gave this obstacle a rating of 1 or 2 . In fact, over half of the women viewed old boy networks as a 'major obstacle', assigning it a rating of 5 or 6 and, of this group, $21.52 \%$ gave this obstacle the highest possible rating.

Although not as striking a contrast, men also saw women's ability to establish credibility as less of a problem than did their female counterparts. Only $15.45 \%$ of the women, but $45.76 \%$ of the men, believed that credibility was a minor concern for women in the lodging industry. On the other end of the scale, $5.23 \%$ of the men but $21.52 \%$ of women viewed lack of credibility as a major obstacle for women managers.

\section{Discussion}

The number of women general managers who have spent fewer than 10 years in the industry is four times greater than the number of men. This finding should encourage a reasonably optimistic picture of the rate at which women are moving into senior level 
management positions. If progress continues, we might expect that even five years from now the number of women general managers will have grown dramatically. This increase may also provide opportunities for more women to manage larger properties, a dimension that continues to be gender-linked.

Although women are advancing rapidly, the question becomes, 'At what cost?' Given what we know about the characteristics of the hospitality environment, it should not be surprising that over a third of the female general managers are single. What is surprising is the gender difference; less than $7 \%$ of the men surveyed were unmarried. The impact of a career focus appears, from the findings of this study, to have more of an impact on the personal lives of women than of men. The number of single women general managers is significantly greater than both the sample of male general managers and American women of that age group generally (U.S. Bureau of the Census, 1992). The long and irregular hours, necessary relocation, and other job characteristics have likely caused many women to indefinitely postpone marriage and families or perhaps to reconsider their previous marriage relationships.

Over twenty years ago, Dowling (1971) warned women that if they were to compete with men in business, they would have to set and work toward clearly identified career goals rather than just put in long hours, waiting to be recognized for their accomplishments. In this context, it is interesting to note that far more men than women general managers deliberately pursued hospitality educations. Since the percent of women and men entering hospitality management programs is now equal (DelSesto, 1993), an important challenge for both educators and practitioners is to identify strategies for retaining these women and methods to assist them in moving smoothly into senior management positions. 


\section{Career Development Skills and Activities}

Although research has documented the importance of various communication skills to effective management, virtually no previous studies have explored gender-related perceptions of the importance of these communication competencies to career development in the hospitality industry. An earlier study (Brownell, 1991a) examined the communication competencies that middle and general managers perceived to be the most important to hospitality management. Findings suggested that middle managers often focused their attention on the communication competencies required to gain visibility (delegating, motivating, presenting information both orally and in writing)-largely sending skills. General managers, on the other hand, had moved to a position where listening was perceived as the key competence, necessary for such tasks as gathering the best possible information, understanding relationships among various projects or departments, and assessing both employees' concerns and the organization's climate.

This study confirms previous research in demonstrating that general managers of both genders value effective listening over virtually all other communication skills. The ability, particularly in a rapidly changing, global industry, to understand and empathize with others is prerequisite to effective leadership in lodging organizations. Today more than ever before, hospitality managers act as members of teams to create high quality service cultures.

The increasing emphasis on group development and team building was expressed in respondents' high ratings of group leadership skills. The total mean of 5.47 put group leadership skills just below listening in perceived importance to managers' career development. As managers strive to further empower employees by sharing responsibility for decision making and by giving them a voice in the organization's future, the usefulness of group leadership skills, and 
the recognition of these competencies as essential tools for influencing the organization's culture, will certainly increase.

The contrast between the perceived importance of written compared to oral communication for career development is striking. Since earlier studies assessing the importance of various communication competencies indicate that effective written communication is highly valued, this apparent discrepancy may illustrate one of the differences between skills perceived as important for daily management activities and those perceived to be tied more closely to career advancement. The slightly greater importance given to written communication by women in the study may be explained by the fact that they are less connected to the informal oral information networks. Women may therefore choose to exert influence through the written communication channels with which they feel more comfort and over which they perceive themselves to have more control (Hirokawa and Kodama, 1990).

The only significant difference in the ratings assigned by men and women to the various communication skills pertained to the importance of effective feedback to career development. Women in the study felt more strongly than did men that accurate feedback was related to their ability to advance to upper level management positions. This finding is consistent with the literature pertaining to gender differences; women are generally thought to seek out opinions more frequently and to depend more heavily than men on others' responses for guidance in shaping their behavior (McCarty, 1986). In addition, there is reason to believe that accurate and systematic feedback on their job performance enables women to overcome any societal factors that may cause them to demonstrate lower self-esteem than their male counterparts (Snyder, 1993; Martinko and Gardner, 1982) 
Men and women were in strong agreement regarding the extent to which they felt various activities and circumstances influenced their career advancement. It appears that nothing replaces hard work as a key to success in the hospitality industry; however, a positive, 'can do' attitude, excellent communication skills, and problem solving ability are also essential ingredients for those who aspire to upper management positions. Based on previous literature, none of these four factors should make senior level positions less accessible to women.

Earlier research suggests that women 'work harder' than do men to accomplish the same career goals. Gregg and Johnson (1990), for instance, note that the women in their survey felt that they had to work twice as hard and do twice as good a job as their male colleagues in order to prove they deserved a promotion. Brownell (1993), in her study of women in middle management, reported very similar results. Yet, the male general managers in this sample reported that hard work was as significant a factor in their career development as did the women. By the same token, men also rated personal sacrifice as more of an obstacle to their career advancement than did women. One explanation may be that significantly greater numbers of men are married and balancing families and careers; a much larger proportion of the women, as discussed earlier, made a choice to pursue their careers rather than marry.

The significant difference between the samples of men and women with regard to ratings of the importance of mentoring to their career development also seems reasonable. Numerous studies have reported lack of mentors as one of the main career obstacles women confront; those women who have been successful have done so largely without benefit of mentoring. The informal networks in which men regularly participate, by contrast, provide greater opportunities for establishing important personal relationships with senior managers. 


\section{Obstacles to Career Development}

While men and women tend to agree on the relative importance of various obstacles to women's career development, there is a strong and somewhat disturbing difference in the degree to which the two samples perceive these obstacles to be a problem to women. Note, for instance, that the mean rating of the male general managers' second highest item, job characteristics, was 3.26. Although this figure is high relative to the men's other rankings, it is lower than six of the eight items rated by the sample of women.

What does this difference in perceptions mean? The most obvious conclusion is that, although men recognize that women confront a variety of career challenges, they simply do not perceive these items to be as significant as women report. This discrepancy may have implications for how men in general management positions prioritize their formal and informal organizational practices pertaining to women's career development, and how they view the special challenges of women relative to the needs of other minority groups.

With regard to the relative significance of the various obstacles to women's career development, there was a generally high level of agreement between the samples of men and women general managers. Women indicated that the two main obstacles, in rank order, were old boy networks and conflicts between family and work. Men ranked family and work conflicts first, job characteristics second, and informal male networks third.

Lack of knowledge and sexual harassment were not rated as major concerns for women in the industry by either male or female samples. It appears that women feel, and are perceived by men to be, well qualified to move into upper level management and that, if harassment occurs on the job, it is an issue women believe they can manage. It may also be that those women who felt less able or willing to handle potentially harassing situations did not choose to stay in an 
industry associated with gender-linked behavior (Eller, 1990; Aaron and Dry, 1992; Laudadis, 1988; Nozar, 1990).

One of the items on which men and women were in highest agreement was with regard to the extent to which family and job conflicts affected women at work. This was also the variable that men believed most influenced women's career development. Family vs. work conflicts appear to be a dimension that both genders fully understand; men rated personal sacrifice even higher (5.09 vs. 4.89) than did women as a factor that has influenced their careers. This finding is consistent with earlier studies (Rosener, 1990) that report just as many men as women experience work vs. family conflicts.

Regarding this issue, Snyder (1993) hypothesizes that men are less comfortable with acknowledging their family commitments and are therefore more likely than are women to reconcile work/family conflicts in nonpublic ways, such as failing to pursue opportunities for advancement. Whereas (as noted earlier) the expectation that women will favor family over career is likely to adversely affect their career development, the expectation that men will put their career ahead of their family may result in highly stressful situations for men in demanding, upper-level management positions (Rosen and Jerdee, 1974). While the literature has focused on the difficulties women experience balancing families and a career (Cook, 1987), the impact of job characteristics and the conflicts men experience cannot be overlooked.

The greatest difference between the ratings of men and women pertained to pay and promotions. As Snyder (1993) and others have warned, when the view upward is predominantly male, women are likely to move elsewhere to pursue their careers. In addition, Fisher (1992) is among the many authors who report significant pay discrepancies between men and women. Although most studies have been conducted in Fortune 500 companies, it is unlikely that pay 
equity exists to a greater extent in the lodging industry. In fact, findings by Gregg and Johnson (1990) indicate that men and women's perceptions of salary equity differ significantly and that, while men were 'unsure' of the situation with regard to equity, the women hospitality managers in their study 'strongly perceived' a salary discrepancy favoring men.

\section{Obstacles to Career Development}

While men and women tend to agree on the relative importance of various obstacles to women's career development, there is a strong and somewhat disturbing difference in the degree to which the two samples perceive these obstacles to be a problem to women. Note, for instance, that the mean rating of the male general managers' second highest item, job characteristics, was 3.26. Although this figure is high relative to the men's other rankings, it is lower than six of the eight items rated by the sample of women.

What does this difference in perceptions mean? The most obvious conclusion is that, although men recognize that women confront a variety of career challenges, they simply do not perceive these items to be as significant as women report. This discrepancy may have implications for how men in general management positions prioritize their formal and informal organizational practices pertaining to women's career development, and how they view the special challenges of women relative to the needs of other minority groups.

With regard to the relative significance of the various obstacles to women's career development, there was a generally high level of agreement between the samples of men and women general managers. Women indicated that the two main obstacles, in rank order, were old boy networks and conflicts between family and work. Men ranked family and work conflicts first, job characteristics second, and informal male networks third. 
Lack of knowledge and sexual harassment were not rated as major concerns for women in the industry by either male or female samples. It appears that women feel, and are perceived by men to be, well qualified to move into upper level management and that, if harassment occurs on the job, it is an issue women believe they can manage. It may also be that those women who felt less able or willing to handle potentially harassing situations did not choose to stay in an industry associated with gender-linked behavior (Eller, 1990; Aaron and Dry, 1992; Laudadis, 1988; Nozar, 1990).

One of the items on which men and women were in highest agreement was with regard to the extent to which family and job conflicts affected women at work. This was also the variable that men believed most influenced women's career development. Family vs. work conflicts appear to be a dimension that both genders fully understand; men rated personal sacrifice even higher (5.09 vs. 4.89) than did women as a factor that has influenced their careers. This finding is consistent with earlier studies (Rosener, 1990) that report just as many men as women experience work vs. family conflicts.

Regarding this issue, Snyder (1993) hypothesizes that men are less comfortable with acknowledging their family commitments and are therefore more likely than are women to reconcile work/family conflicts in nonpublic ways, such as failing to pursue opportunities for advancement. Whereas (as noted earlier) the expectation that women will favor family over career is likely to adversely affect their career development, the expectation that men will put their career ahead of their family may result in highly stressful situations for men in demanding, upper-level management positions (Rosen and Jerdee, 1974). While the literature has focused on the difficulties women experience balancing families and a career (Cook, 1987), the impact of job characteristics and the conflicts men experience cannot be overlooked. 
The greatest difference between the ratings of men and women pertained to pay and promotions. As Snyder (1993) and others have warned, when the view upward is predominantly male, women are likely to move elsewhere to pursue their careers. In addition, Fisher (1992) is among the many authors who report significant pay discrepancies between men and women. Although most studies have been conducted in Fortune 500 companies, it is unlikely that pay equity exists to a greater extent in the lodging industry. In fact, findings by Gregg and Johnson (1990) indicate that men and women's perceptions of salary equity differ significantly and that, while men were 'unsure' of the situation with regard to equity, the women hospitality managers in their study 'strongly perceived' a salary discrepancy favoring men.

In 1992 Brownell conducted a study of 287 women middle managers in the hospitality industry, posing a virtually identical set of potential obstacles to this sample and asking for their ratings of the significance of each item. A comparison of the perceptions of women in general management to those in middle management reveal striking differences in mean ratings for such items as credibility, family and work conflicts, pay and promotions, the importance of job knowledge, and the role of mentoring (Table 5). It appears that the stage a women is at in her career development influences her perceptions of the obstacles women confront. It may be that women in middle management and those in senior management positions each pay attention to different aspects of their work environment.

One of the most significant differences between the samples of women middle and general managers pertained to perceptions of the importance of mentoring to career development. While women in middle management perceived lack of mentoring as the second most significant obstacle (mean of 4.62), women general managers rated mentoring as much less of an important factor (mean of 3.37). Perhaps this is accounted for by the fact that the women 
general managers indicated that they themselves did not rely heavily on a mentor for their own career advancement, while women entering the industry in the 1990s have different expectations.

The recent attention given to the value and necessity of mentoring may affect perceptions of its significance; current research is exploring the impact of women's changing expectations regarding what the hospitality workplace should be like on their perceptions of various careerrelated variables and their satisfaction with their work environment. Such explanations cannot be given for the difference between the two groups regarding perceptions of the degree to which pay and promotions are an obstacle to career development. Gender differences with regard to pay appear to widen as women move into senior positions. This dimension clearly requires further study.

There were also similarities between these two groups of women. Perhaps most noteworthy was that the old boy network was seen as a significant obstacle to both women in middle management (mean of 4.89) and general managers (mean of 4.42), ranking first in significance of all potential career obstacles for both samples. The ratings women in middle management assigned to harassment and job knowledge were consistent with the two general manager samples; they did not perceive either as a significant obstacle to women's career advancement.

\section{Implications and Future Directions}

It has never been easier for qualified women to establish successful careers in the lodging industry, and there is every reason to believe that conditions will continue to improve. This does not imply, however, that the majority of women do not confront significant challenges to their career development. Both educators and practitioners must take responsibility for preparing women to confront workplace demands and for ensuring that the workplace becomes an 
increasingly supportive, healthy environment in which women can realize their unique contributions to hospitality management.

In our classrooms and in the field, those interested in creating the best possible hospitality organizations must hear women's concerns and take note. Formal programs, initiated at either the corporate or property levels, might further facilitate women's careers. Recognizing the impact of traditional male-dominated communication patterns, like the old boy networks, on women's performance and taking measures to create more inclusive and empowering environments, is another step toward valuing diversity.

All of the questions have not yet been asked; there are still missing pieces needed to create a complete picture of women in the hospitality workplace. This study was intended to guide future efforts to formulate the questions that will move both educators and practitioners closer to finishing the story. Survey research, in spite of inherent limitations, provides one of the best methods available for hearing a range of voices speak to important issues. Women's career development is one of these issues, and the men and women who have moved to upper level management positions have spoken with conviction about their hospitality careers. 


\section{References}

Aaron, R. and Dry, E. (1992) Sexual harassment in the hospitality industry. Cornell Hotel and Restaurant Administration Quarterly 33(2), 93-95.

Anthony, C. (1986) Publication relations: Successful women in the lodging industry. Hotel \& Resort Industry 9(19).

Bernstein, C. (1990) Unified effort vital to women's advancement: Stereotypes remain barrier to executive suite. Nation's Restaurant News 24(25), 29.

Blanksby, M. (1987) In their own words: The clues to how to develop women managers. Women in Management Review 3(2), 71-77.

Brass, D. J. (1985) Men's and women's networks: A study of interaction patterns and influence in an organization. Academy of Management Journal 28, 327-343.

Brownell, J. (1993) Women hospitality managers: Perceptions of gender-related career challenges. FIU Hospitality Review 11(2), 19-31.

Brownell, J. (1991a) Hospitality managers' communication practices. The International Journal of Hospitality Management 11(2), 111-128.

Brownell, J. (1991b) SHA Tracking Study, Unpublished paper. 31 pages. Ithaca, NY: School of Hotel Administration, Cornell University.

Burke, R. J. and McKeen, C. A. (1990) Mentoring in organizations: Implications for women. Journal of Business Ethics 9(4,5), 317-332.

Campbell, K. E. (1988) Gender differences in job-related networks. Work and Occupations $15(2), 179-200$.

Carbone, L. (1992) Women at work: Breaking the glass...or just window dressing? Management Review 8(3). 16-22. 
Christensen, J. (1987) Educator's forum: Women in management: Advice to recent graduates. Cornell Hotel \& Restaurant Administration Quarterly 28(3), 48-49.

Chusmir, L. H. (1982) Job commitment and the organizational women. Academy of Management Review 7, 595-602.

Cohen, H. and Neilson, E. H. (1988) Finding and developing tomorrow's top managers. Cornell Hotel \& Restaurant Administration Quarterly 29(1). 34-41.

Cook, A. H. (1987) Work and family: Juncture and disjuncture. ILR Report 25(1), 5-9.

DelSesto, C. (1993) Women in lodging: How far have they come? Lodging May, 29-32.

DeLuca. M. (1988) Female lodging executives dealing with glass ceiling. Hotel \& Motel Management 203(15), 10.

DeWine, S. and Smith, G. L. (1991, December) Perceptions of subordinates and requests for support. Group and Organization Studies 16(4), 408-427.

Dowling, C. (1971) The Cinderella complex. Summit Books, Inc., New York.

Dreher, G. F. and Ash, R. A. (1990) A comparative study of mentoring among men and women in managerial, professional, and technical positions. Journal of Applied Psychology 75(5). 539-546.

Eller, M. E. (1990) Sexual harassment: Prevention, not protection. Cornell Hotel and Restaurant Administration Quarterly 30(4). 84-89.

Fernsten, J. A., Loury, L. L., Enghagen. L. K. and Hott, D. (1988) Female managers: Perspectives on sexual harassment and career development. Hospitality Education and Research Journal 12(2), 185-196.

Fisher, A. B. (1992) When will women get to the top? Fortune September, 44-56. 
Gregg. J. B. and Johnson, P. M. (1990) Perceptions of discrimination among women as managers in hospitality organizations. F.I.U. Hospitality Review 8(1), 10-22.

Haskell, J. R. (1991) A new look at women executives. Executive Excellence 8(1). 13-14.

Hirokawa, R. Y. and Kodama, R. A. (1990) Impact of managerial power on persuasive strategy selection by female and male managers. Management Communication Quarterly August, $30-48$.

Ibarra, H. (1993) Persona1 networks of women and minorities in management: A conceptual framework. Academy of Management Review 18(1), 56-87.

Kalinowski. T. (1989) The right stuff. Canadian Hotel \& Restaurant 67(3), 56.

Lambert. S. J. (1990) Processes linking work and family: A critical review and research agenda. Human Relations 43, 239-257.

Laudadis. D. M. (1988) Sexual and gender harassment: Assessing the current climate. Hospitality Education and Research Journal 12(2), 411-415.

Lobel, S. A. (1991) Allocation of investment in work and family roles: Alternative theories and implications for research. Academy of Management Review 16(3), 507-521.

Lobel, S. A. and St. Clair, L. (1992) Effects of family responsibilities, gender, and career identity salience on performance outcomes. Academy of Management Journal 35(5), 1057-1069.

Martinko, M. J. and Gardner. W. L. (1982) L earned helplessness: An alternative explanation for performance deficits. Academy of Management Review 7, 195-205.

McCarty. P. (1986) Effects of feedback on self-confidence of men and women. Academy of Management Journal 29, 840-846.

Noe, R. A. (1988) Women and mentoring: A review and research agenda. Academy of Management Review 13(1), 65-78. 
Nozar, R. (1990) Winking at sexual harassment demeans lodging. Hotel and Motel Management 205(7), 6-7.

Ostroff, C. (1993) Relationships between person-environment congruence and organizational effectiveness. Group \& Organization Management 18(1), 103-122.

Ragins, B. R. and Cotton, J. L. (1991) Easier said than done: Gender differences in perceived barriers to gaining a mentor. Academy of Management Journal 34(4), 939-951.

Rosen, B. and Jerdee, T. H. (1974) Sex stereotyping in the executive suite. Harvard Business Review, 45-58.

Rosen, B., Templeton, M. E. and Kichline, K. (1982) The first few years on the job: Women in management. Business Horizons 24(6), 26-29.

Rosener, J. (1990) Ways women lead. Harvard Business Review 68(6), 119-125.

Rosin, H. M. and Korabik, K. (1990) Marital and family correlates of women managers' from organizations. Journal of Vocational Behavior 37, 104-120.

Rossi, P. H. (1966) Research strategies in measuring peer group influence, in T. M. Newcomb and E. K. Wilson (Eds.), College Peer Groups, pp. 190-232. Aldine Publishers, Chicago, IL.

Scandura, T. A. (1992) Mentorship and career mobility: An empirical investigation. Journal of Organizational Behavior.

Schwartz, F. N. (1989) Management women and the new facts of life. Harvard Business Review 67(1), 65-76.

Segal. A. T. and Zellner, W. (1992) Corporate women. Business Week June, 74-78.

Silberman, R. G. (1991, June) Executive intelligence: A glass ceiling. Restaurant Hospitality 75(6). 65 . 
Snyder, R. A. (1993) The glass ceiling for women: Things that don't cause it and things that won't break it. Human Resource Development Quarterly 4(1), 97-107.

Stroh. L., Brett, J. M. and Reilly, A. H. (1992) All the right stuff: A comparison of female and male managers' career progression. Journal of Applied Psychology 77, 251-260.

Trost, C. (1990) Women managers quit not for family but to advance their corporate climb. Wall Street Journal May 2. B1-B2.

U.S. Department of Labor (1991) A Report on the Glass Ceiling Initiative. Office of Information and Public Affairs, Washington, D.C.

U.S. Bureau of the Census (1992) Marital status. Current population reports, series P-20. No. 461, 43-45.

Wentling, R. A. (1992) Women in middle management: Their career development and aspirations. Business Horizons 35(1), 47-54.

Williams, P. W. and Hunter, M. (1992) Supervisory hotel employee perceptions of management careers and professional development requirements. International Journal of Hospitality Management 11(4), 347-358. 
Table 1. Demographic information for male and female general managers (\% of men and women)

\begin{tabular}{|c|c|c|}
\hline & Women $(n=97)$ & $\operatorname{Men}(n=221)$ \\
\hline \multicolumn{3}{|l|}{ Age categories } \\
\hline under 30 & 15.8 & 5.1 \\
\hline $31-35$ & 24.4 & 16.0 \\
\hline $36-40$ & 27.6 & 34.6 \\
\hline $41-45$ & 20.7 & 25.0 \\
\hline $46-50$ & 6.1 & 11.5 \\
\hline over 50 & 5.3 & 7.7 \\
\hline \multicolumn{3}{|l|}{ Years in the industry } \\
\hline under 10 & 43.4 & 10.9 \\
\hline $11-20$ & 50.5 & 50.6 \\
\hline over 20 & 6.1 & 38.5 \\
\hline \multicolumn{3}{|l|}{ Marital Status } \\
\hline Single & 34.9 & 6.4 \\
\hline Separated/divorced & 21.3 & 10.9 \\
\hline Married & 43.8 & 82.7 \\
\hline
\end{tabular}


Table 2. Perceptions of the communication competencies that contribute to career development: $\%$ of total sample assigning each rating

\begin{tabular}{|c|c|c|c|c|c|c|}
\hline \multicolumn{7}{|l|}{ Men and Women $(n=318)$} \\
\hline & \multicolumn{6}{|c|}{ Importance to career development } \\
\hline & \multicolumn{2}{|c|}{ Low } & \multicolumn{2}{|c|}{ Moderate } & \multicolumn{2}{|c|}{ High } \\
\hline Communication competencies & 1 & 2 & 3 & 4 & 5 & 6 \\
\hline Effective listening & 0.00 & 0.00 & 0.00 & 6.46 & 33.19 & 60.34 \\
\hline Group leadership & 0.00 & 0.00 & 1.72 & 4.31 & 38.76 & 55.17 \\
\hline Clear oral communication & 0.00 & 0.43 & 1.72 & 9.91 & 45.26 & 42.68 \\
\hline Effective feedback & 0.00 & 0.00 & 1.72 & 13.36 & 48.71 & 36.21 \\
\hline Clear written communication & 0.86 & 4.31 & 10.78 & 40.09 & 30.17 & 13.79 \\
\hline Presentational speaking & 3.45 & 4.31 & 19.83 & 26.72 & 30.60 & 15.09 \\
\hline
\end{tabular}


Table 3. Perceptions of the communication competencies that contribute to career development: means $(\mathrm{M})$, standard deviations (SD) and (t) scores

\begin{tabular}{|c|c|c|c|c|c|}
\hline $\begin{array}{l}\text { Communication } \\
\text { competencies }\end{array}$ & & $\begin{array}{c}\text { Men \& Women } \\
(n=318)\end{array}$ & $\begin{array}{l}\text { Women } \\
(\mathrm{n}=97)\end{array}$ & $\begin{array}{c}\text { Men } \\
(n=221)\end{array}$ & $\begin{array}{c}\text { Difference Women } \\
\& \text { Men }(\mathrm{t})\end{array}$ \\
\hline Effective & $M$ & 5.52 & 5.81 & 5.48 & 1.55 \\
\hline listening & $S D$ & 0.631 & 0.586 & 0.651 & \\
\hline Group & $M$ & 5.47 & 5.44 & 5.47 & 0.474 \\
\hline leadership & $S D$ & 0.662 & 0.669 & 0.661 & \\
\hline Clear oral & $M$ & 5.27 & 5.24 & 5.29 & 0.506 \\
\hline communication & $S D$ & 0.746 & 0.835 & 0.698 & \\
\hline Effective & $M$ & 5.19 & 5.34 & 5.11 & $-2.28 *$ \\
\hline feedback & $S D$ & 0.728 & 0.765 & 0.698 & \\
\hline Clear written & $M$ & 4.37 & 4.50 & 4.30 & 0.573 \\
\hline communication & $S D$ & 1.02 & 1.01 & 0.970 & \\
\hline Presentational & $M$ & 4.24 & 4.12 & 4.30 & 0.982 \\
\hline speaking & $S D$ & 1.21 & 1.42 & 1.09 & \\
\hline
\end{tabular}

$* p \leq 0.05$.

Ratings of the importance of each item were made on 6-point Likert scales from 1 (low) to 6 (high). 
Table 4. Activities and circumstances contributing to career development: means (M), standard deviations (SD) and (t) scores

\begin{tabular}{|c|c|c|c|c|c|}
\hline $\begin{array}{l}\text { Factors influencing } \\
\text { career development }\end{array}$ & & $\begin{array}{c}\text { Men \& Women } \\
(n=318)\end{array}$ & $\begin{array}{l}\text { Women } \\
(n=97)\end{array}$ & $\begin{array}{c}\text { Men } \\
(n=221)\end{array}$ & $\begin{array}{c}\text { Difference Women } \\
\text { \& Men (t) }\end{array}$ \\
\hline \multirow[t]{2}{*}{ Hard work } & $M$ & 5.58 & 5.59 & 5.57 & 0.292 \\
\hline & $S D$ & 0.575 & 0.588 & 0.570 & \\
\hline \multirow[t]{2}{*}{ Attitude } & $M$ & 5.51 & 5.44 & 5.55 & 1.35 \\
\hline & $S D$ & 0.573 & 0.593 & 0.560 & \\
\hline Effective & $M$ & 5.34 & 5.39 & 5.32 & -0.816 \\
\hline communication & $S D$ & 0.647 & 0.628 & 0.655 & \\
\hline \multirow[t]{2}{*}{ Problem solving } & $M$ & 5.30 & 5.32 & 5.29 & -0.330 \\
\hline & $S D$ & 0.694 & 0.634 & 0.724 & \\
\hline \multirow[t]{2}{*}{ Personal sacrifice } & $M$ & 5.03 & 4.89 & 5.09 & 1.51 \\
\hline & $S D$ & 0.941 & 0.961 & 0.927 & \\
\hline \multirow[t]{2}{*}{ Personality } & $M$ & 4.96 & 5.02 & 4.92 & 0.848 \\
\hline & $S D$ & 0.823 & 0.831 & 0.820 & \\
\hline \multirow[t]{2}{*}{ Job knowledge } & $M$ & 4.84 & 4.70 & 4.90 & 1.38 \\
\hline & $S D$ & 0.991 & 1.12 & 0.910 & \\
\hline \multirow[t]{2}{*}{ Mentoring } & $M$ & 4.19 & 3.88 & 4.34 & $2.49 *$ \\
\hline & $S D$ & 1.15 & 0.628 & 0.952 & \\
\hline \multirow[t]{2}{*}{ Education } & $M$ & 3.80 & 3.66 & 3.88 & 1.41 \\
\hline & $S D$ & 1.09 & 1.15 & 1.05 & \\
\hline \multirow[t]{2}{*}{ Lucky breaks } & $M$ & 3.38 & 3.24 & 3.31 & 1.15 \\
\hline & $S D$ & 1.28 & 1.22 & 1.20 & \\
\hline
\end{tabular}

$* p \leq 0.05$ 
Table 5. Extent of perceived obstacle to career development by men and women general managers and by women in middle management: means (M), standard deviations (SD), and (t) scores

\begin{tabular}{|c|c|c|c|c|c|}
\hline & & $\begin{array}{l}\text { Women middle } \\
\text { managers } \\
(n=287)\end{array}$ & $\begin{array}{l}\text { Women GM } \\
(n=97)\end{array}$ & $\begin{array}{l}\text { Men GM } \\
(n=221)\end{array}$ & $\begin{array}{c}\text { Difference } \\
\text { between women } \\
\text { and men GMs (t) }\end{array}$ \\
\hline \multirow[t]{2}{*}{ Old boy network } & $M$ & 4.89 & 4.42 & 3.07 & $-7.30 * *$ \\
\hline & $S D$ & 0.701 & 1.26 & 1.43 & \\
\hline Family \& work & $M$ & 3.05 & 4.36 & 4.01 & $-2.01 *$ \\
\hline conflict & $S D$ & 1.29 & 1.24 & 1.27 & \\
\hline Pay and & $M$ & 2.89 & 4.03 & 2.56 & $-7.61 * *$ \\
\hline promotions & $S D$ & 1.68 & 1.29 & 1.37 & \\
\hline \multirow[t]{2}{*}{ Job characteristics } & $M$ & 3.51 & 3.72 & 3.26 & $-2.20 *$ \\
\hline & $S D$ & 1.56 & 0.978 & 1.55 & \\
\hline \multirow[t]{2}{*}{ Lack of mentors } & $M$ & 4.62 & 3.37 & 2.94 & $-2.12 *$ \\
\hline & $S D$ & 1.19 & 1.43 & 1.46 & \\
\hline \multirow[t]{2}{*}{ Lack of credibility } & $M$ & 2.44 & 3.62 & 2.63 & $-5.75 * *$ \\
\hline & $S D$ & 1.44 & 1.22 & 1.22 & \\
\hline \multirow[t]{2}{*}{ Sexual harassment } & $M$ & 2.06 & 2.87 & 2.44 & $-2.34 *$ \\
\hline & $S D$ & 1.38 & 1.41 & 1.06 & \\
\hline Lack of job & $M$ & 1.43 & 2.60 & 2.29 & -1.42 \\
\hline knowledge & $S D$ & 0.672 & 1.46 & 1.51 & \\
\hline
\end{tabular}

$* p \leq 0.05 ; * * p \leq 0.001$

Information on women in middle hospitality management is from an earlier study (Brownell, 1993). 